\title{
Development of organizational and economic instruments for enhancing the innovation process in major construction
}

\author{
Violetta Politi* \\ Moscow State University of Civil Engineering, Yaroslavskoe shosse, 26, Moscow, 129337, Russia
}

\begin{abstract}
Objectively, there is discrimination in relation to investments in inventions and research activities, since the risk is higher, the inhibition of funds is longer, and the investment analysis of innovative projects is longer and more laborious. Consequently, in order to enhance innovation in the construction industry, it is necessary to develop specific instruments for state stimulation. One of these tools is a priority form of government funding for projects with a high level of use of innovations in architectural and design solutions. The development of a methodology for assessing the level of novelty and progressiveness of design solutions will make it possible to make their justified selection for priority government funding
\end{abstract}

\section{Introduction}

Nowadays, the ability to create and apply innovative technologies is a primary condition for both economic independence and effective participation of a country in the global economy and a decent standard of living for its population. The development of instruments and methods for enhancing innovation processes in the construction industry, as part of an innovative organizational and economic mechanism for managing the national innovation system, will allow achieving the strategic goals set as the basis for the scientific, technical and technological development of Russia.

To effectively solve the problems of increasing the rate of commissioning of residential facilities, for the implementation of large-scale infrastructure construction projects that contribute to strengthening the industrial potential of the Russian Federation as a whole, the construction industry needs state support in the area of enhancing the introduction of innovations. (Tab.1).

Based on the data of statistical tables 1,2 , we can conclude that the innovative activity of the construction industry in Russia is low compared to other sectors of the economy, such as industrial production and the service sector.

State support is a necessary prerequisite for resource provision of innovative activities.

\footnotetext{
* Corresponding author: polity_violca@list.ru
} 
Table 1. Development of innovation processes in leading sectors of the economy for the period of 2018 [1]

\begin{tabular}{|c|c|c|c|c|c|}
\hline \multirow{3}{*}{$\begin{array}{l}\text { Types of } \\
\text { economic } \\
\text { activity }\end{array}$} & \multirow{3}{*}{$\begin{array}{c}\text { Share of } \\
\text { organizations } \\
\text { implementing } \\
\text { technological } \\
\text { innovations }\end{array}$} & \multirow{2}{*}{\multicolumn{2}{|c|}{$\begin{array}{l}\text { Innovative goods, } \\
\text { services in total } \\
\text { production }\end{array}$}} & \multicolumn{2}{|c|}{$\begin{array}{c}\text { Cost of technological } \\
\text { innovation }\end{array}$} \\
\hline & & & & \multirow[b]{2}{*}{$\begin{array}{l}\text { volume, } \\
\text { billion rubles }\end{array}$} & \multirow[b]{2}{*}{ intensity, $\%$} \\
\hline & & $\begin{array}{l}\text { volume, } \\
\text { billion } \\
\text { rubles } \\
\end{array}$ & share, $\%$ & & \\
\hline $\begin{array}{l}\text { Industrial } \\
\text { production }\end{array}$ & $18.5 \%$ & 3691.3 & 6.0 & 886.8 & 1.4 \\
\hline Services sector & $21.4 \%$ & 789.3 & 13.7 & 564.0 & 8.8 \\
\hline Construction & $9.5 \%$ & 0.05 & 0.03 & 0.05 & 0.003 \\
\hline Agriculture & $6.4 \%$ & 33.8 & 1.9 & 22.0 & 1.2 \\
\hline
\end{tabular}

In 2019 , the level of innovative activity of organizations was $9.1 \%$, which is lower than in previous years $(2018-12.8 \%$, in $2017-14.6 \%)$. The volume of innovative products manufactured in 2019 reached 4.86 trillion. But its share in total sales is only about $5 \%$. The exception is high-tech industries, where the effectiveness of innovation activity is comparable to the average level in the leading European countries: $18.1 \%$ versus $12 \%$ in Austria, 13.6\% in Belgium, 15.5\% in Great Britain, 14.0\% in Germany (Tab. 2).

Table 2. Development of innovative processes in leading sectors of the economy for the period 2019-2020 [2]

\begin{tabular}{|l|c|c|c|c|}
\hline \multirow{2}{*}{ Types of economic activity } & \multicolumn{2}{|c|}{$\begin{array}{c}\text { Innovative goods, services in } \\
\text { total production }\end{array}$} & \multicolumn{2}{c|}{$\begin{array}{c}\text { Share of innovatively active } \\
\text { companies, \% }\end{array}$} \\
\cline { 2 - 5 } & $\begin{array}{c}\text { volume, billion } \\
\text { rubles }\end{array}$ & share, \% & $2019-2020$ & Plan for 2021 \\
\hline Industrial production & 3871.5 & & 15.1 & 15.2 \\
\hline Services sector & 892.4 & & 7.6 & 9.2 \\
\hline Construction & 30.0 & & 3.7 & 3.7 \\
\hline Agriculture & 69.6 & & 4.2 & 7.3 \\
\hline
\end{tabular}

Based on the study of international experience, characteristics and problems of creating national innovation systems, it should be stated that at the initial stage of the creation and development of elements of the national innovation system, there is discrimination against investments in innovative research, development and implementation in practice. Thus, the economist K. Arrow, whose works have become classical, wrote that there is objectively discrimination in relation to investments in inventions and research activities, since the risk is higher and the deadlock of funds is longer, and the investment analysis of innovative projects is longer and more laborious.

The first level in the hierarchy of causal factors is the slow formation and development of a culture of innovative entrepreneurship in construction, which is characterized by internal motivation and a high degree of readiness to implement resourcesaving projects with care for future generations, but at the same time, highly risky projects with a long payback period. The process of introducing an innovative idea presupposes both the availability of state support and a constant lack of knowledge and specific skills. They are acquired in the process of working on a project, huge resources are spent on selfeducation, which leads to the formation of a unique economic, social and cultural capital [3-5].

The second level of causal factors is a low level of entrepreneurial confidence, formed by the lack of construction orders for a ready-made production program, chronic insolvency of representatives of the construction business in Russia. The solution to this problem, as the author sees it, is in the initiation of sectoral clustering according to the territorialregional principle. 
The third level in the hierarchy of causal factors hindering the innovative development of major construction is the presence of a large number of participants, technological features of the construction process and responsibility to the customer and consumer for the quality and safety of the final product. The construction site must comply with the requirements of national standards, building and sanitary norms, rules and methodological documents that guarantee the safety, reliability, comfort and durability of the object [6-9].

Let's make a grouping of the main obstacles to the use of innovative developments in the construction industry (Tab. 3).

Table 3. Strategic development directions and constraints

\section{Functional areas and causal constraints}

\section{Strategic areas of innovative development}

\section{Engineering survey}

The main representatives are micro-enterprises (about $70 \%$ ) with a worn-out fund; $24 \%$ are medium-sized businesses and about $6 \%$ are large businesses development of satellite navigation systems

high cost of modern imported equipment

lag in the development of domestic technical means and technologies for survey work

lack of a competitive procedure for receiving an order

replacement of domestic equipment and technologies with imported, more advanced analogues

widespread transition to the use of laser scanning techniques

Creation of a register of innovative developments

improving the work of state institutions for the protection of intellectual property

creation of a system for engineering monitoring of complex objects and hazardous processes based on modern technologies

\section{Architectural and construction design}

imperfection of the legal and regulatory framework for design, imperfection of methodology and design technology, including in standard design imperfection of mechanisms ensuring the timely inclusion of innovations in the documents of technical regulation of the construction industry

imperfection of the institute for examination of design documentation and the results of engineering surveys development of standards for information modeling, predictive mathematical modeling and digital formation of urban planning and project documentation with criteria for reliability and responsibility

harmonization of Russian legislation, including the system of technical regulation and professional certification, with international standards

development of a standard design system based on the creation of digital databases of re-use projects, standard projects, standard design solutions, including standard specifications, standard building structures, standard structural series, standard parts, products and assemblies, and organizing access to these databases

lack of a reasonable pricing policy in relation creation of information databases of building materials and process diagrams used in the construction of major construction facilities, including classifiers, catalogs, information on the current cost of materials and work

mers of the cost of such work, low qual of engineering surveys and registration of their results

\section{Building materials and industry of building materials}

actual production load does not exceed 60$80 \%$ of the design capacity energy intensity of the technology for the reducing the consumption of energy and material resources for the production of a unit of production through the use of modern energy-saving and 


\begin{tabular}{|c|c|}
\hline & saving techno \\
\hline $\begin{array}{l}\text { (in the cost of finished products, the share of } \\
\text { expenses for fuel and energy resources is } 30 \text { - } \\
40 \% \text { ) } \\
\text { there is no involvement of waste of economic } \\
\text { activity that can be used in the production of }\end{array}$ & $\begin{array}{l}\text { organization of production of products and } \\
\text { structures for construction using composite } \\
\text { materials, including new generation ceramic } \\
\text { composite materials based on modified raw } \\
\text { materials }\end{array}$ \\
\hline & sing production of energy efficient wall \\
\hline insufficiently dev & building materials \\
\hline $\begin{array}{l}\text { materials and structures for industrial housing } \\
\text { construction } \\
\text { innovative development is constrained by the }\end{array}$ & $\begin{array}{l}\text { use of alternative fuels in technological processes } \\
\text { of production of building materials, including } \\
\text { industrial and municipal solid waste }\end{array}$ \\
\hline & \\
\hline & ovative techr \\
\hline $\begin{array}{l}\text { mechanical } \\
\text { constructior }\end{array}$ & $\begin{array}{l}\text { expansion of production volumes of modern } \\
\text { thermal insulation materials }\end{array}$ \\
\hline . & nt \\
\hline $\begin{array}{l}\text { complicating the tasks of managing } \\
\text { construction production, especially in the } \\
\text { framework of large investment and } \\
\text { construction projects }\end{array}$ & $\begin{array}{l}\text { Implementation of innovative engineering systems } \\
\text { and the use of intelligent technologies in } \\
\text { construction based on the paradigm of perspective } \\
\text { modeling of the life cycle of buildings and }\end{array}$ \\
\hline creation of a single decision-m & \\
\hline $\begin{array}{l}\text { all management levels }- \text { technical, } \\
\text { technological and organizational levels }\end{array}$ & $\begin{array}{l}\text { project management } \\
\text { modeling systems and }\end{array}$ \\
\hline $\begin{array}{l}\text { lack of end-to-end interaction between the } \\
\text { Customer, the General Contractor and the } \\
\text { operating company at the stages of the entire }\end{array}$ & \\
\hline
\end{tabular}

\section{Materials and Methods}

To increase the interest of representatives of the construction industry in the use of innovations, it is necessary to develop an organizational and economic mechanism that will accelerate the course of innovation processes [10].

The author puts forward a hypothesis that it is possible to activate innovation processes only when a specific state mechanism is created, aimed at selecting projects according to the level of application of innovations in design solutions and their further priority financing. In this case, the task is to create a methodology for assessing the level of innovation (progressiveness, novelty) of design solutions, as well as to identify the role and functions of the project office in the state management structure.

In this study, the methodological basis for the concept of progressiveness of an innovative project will be the provisions of systems engineering in construction. A construction project is a complex management, organizational, economic and technological system that can be represented as a model formed from composite organizational and technological modules. Organizational and technological modules are potentials that represent a set of groups of processes united by a single organizational approach, technological sequence, functional purpose, as well as other organizational, technological and managerial factors. It is possible to conduct a study of these potentials based on the decomposition of the goal tree "from simple to complex". The use of an integral parameter in assessing the level of progressiveness and novelty of a construction project will make it possible to identify design solutions by the criterion of innovation.

So, prof. Lapidus A.A. it is proposed to use the concept "integral organizational and technological potential of a construction project" as a tool that allows predicting the achievement of optimal results [11]. According to prof. Lapidus AA, the integral potential 
of a construction project can be assessed on the basis of its linear dependence on a set of individual organizational, technological and managerial potentials [11]:

$$
I P=\sum_{i=1}^{n}\left(W_{i} S I P_{i}\right)=W_{1} w_{1} x_{1}+W_{2} w_{2} x_{2} \ldots+W_{n} w_{n} x_{n}
$$

SIP - organizational and technological potential; $x_{i}$ is the numerical characteristic of the factor influencing the value of the potential; $w_{i}$-factor weighting factor.

In order to activate the introduction of innovations in major construction, the author proposes to expand the powers of Regional Project Management Offices as a state instrument for influencing and regulating investment processes. Currently, the main functions of project management offices are concentrated in consulting, methodological and informational support. At the same time, as the purpose of the project management office is the administration of projects and programs. The project office is a control-coordinating body that decomposes and highlights repeatable business processes, with the goal of improving planning efficiency and the quality of project execution in the future [9-10].

The adoption of a decision on the priority financing of construction projects or reconstruction of facilities with a certain share of architectural and planning, design and engineering innovative solutions at the legislative level, as well as the expansion of the powers of the state project management office should solve the above problem (Table 4). Some of the functions can be outsourced to external organizations, according to the contract for the provision of outsourcing services (Tab. 4).

Table 4. Basic and advanced functions for the formation of a new Regulation for support of investment and innovative projects (case study of Moscow)

\begin{tabular}{|c|c|}
\hline ions & es \\
\hline $\begin{array}{l}\text { 1. providing a "one window" regime for } \\
\text { investors when interacting with executive } \\
\text { authorities; } \\
\text { 2. creating project teams to support and } \\
\text { implement specific investment projects on a } \\
\text { turnkey basis; } \\
\text { 3. promotion of investment opportunities } \\
\text { and projects of the city of Moscow in Russia } \\
\text { and abroad (including through conferences, } \\
\text { exhibitions, forums); } \\
4 \text { ensuring interaction with investment and } \\
\text { venture funds, banks, foreign state investment } \\
\text { agencies, specialized financial institutions, } \\
\text { Russian and international development } \\
\text { institutions in order to use their potential and } \\
\text { opportunities to finance and support investments } \\
\text { in the city of Moscow; } \\
5 \text { support of public-private partnership } \\
\text { projects by the principle of "one window"; } \\
6 \text {. support of investment priority projects by } \\
\text { the principle of "one window" }\end{array}$ & $\begin{array}{l}\text { 7. centralized allocation of project managers } \\
\text { or administrators; } \\
8 \text {. forming a team of experts to assess the } \\
\text { share of innovations in design solutions; } \\
\text { 9. introduction, support and development of a } \\
\text { project motivation system for the use of } \\
\text { innovations; } \\
10 \text {. introduction of an innovative culture } \\
\text { through training and promotion of investment } \\
\text { opportunities and projects in Russia and abroad } \\
\text { through conferences, exhibitions, forums; } \\
\text { 11. organization of training in project } \\
\text { management or training itself; } \\
\text { 12. assistance in planning and monitoring the } \\
\text { implementation of individual projects on request } \\
\text { or on an ongoing basis; } \\
\text { 13. knowledge management in the field of } \\
\text { project management of innovation; } \\
\text { 14. audit of innovative projects }\end{array}$ \\
\hline
\end{tabular}

So, a construction company applies to the state project office with an application for assistance in supporting an innovative project, including assistance from venture funds. A group of experts assesses the technical and economic indicators according to the innovation-efficiency-expediency criteria. The purpose of the assessment is to determine the 
impact of functional, technical, technological and organizational factors of an innovative project on economic results. The result of the assessment is to determine the level of innovativeness of the selected engineering solutions.

To develop the technical and economic argumentation of the proposed innovative solutions for the construction project, the following scope of work can be proposed:

\section{Architectural and design audit of innovations: development and assessment of the novelty of space-planning and design solutions}

Here: Development of a procedure for assessing the effectiveness of an innovative design solution. Drawing up an algorithm for choosing a basic option. Selection and comparison of technical characteristics of the base and the proposed option. Comprehensive assessment of the quality of the basic and proposed options.

2. Technological audit of innovations: development and assessment of the novelty of building technological solutions and applied building materials

Here: development of a procedure for assessing the effectiveness of technological solutions: stages, methods and types of assessment (with and without taking into account the time factor); evaluation criteria, their relationship with the types of evaluation (Tab. 5, $6)$.

Table 5. Scientific and technical novelty audit results

\begin{tabular}{|l|l|c|c|}
\hline No. & \multicolumn{1}{|c|}{ Criterion name } & $\begin{array}{c}\text { Weight } \\
\text { (significance) }\end{array}$ & $\begin{array}{c}\text { Points } \\
\text { (estimate) }\end{array}$ \\
\hline 1 & $\begin{array}{l}\text { Legal protection of the project (compliance with current } \\
\text { and prospective legislation, patent, license, etc.) }\end{array}$ & 0.10 & $\mathrm{X} 1$ \\
\hline 2 & $\begin{array}{l}\text { Product alignment with key innovation trends in the } \\
\text { construction industry }\end{array}$ & 0.30 & $\mathrm{X} 2$ \\
\hline 3 & $\begin{array}{l}\text { The novelty of the proposed product/technology analysis } \\
\text { application of the product }\end{array}$ & 0.20 & $\mathrm{X} 3$ \\
\hline 5 & Ease of implementation of innovative development & 0.15 & $\mathrm{X} 4$ \\
\hline 6 & Availability of scientific and technical resources & 0.10 & $\mathrm{X} 5$ \\
\hline 7 & Production safety level & 0.05 & $\mathrm{X} 6$ \\
\hline 8 & Availability of required equipment & 0.05 & $\mathrm{X} 7$ \\
\hline & Total & $\mathbf{1 . 0 0}$ & $\mathrm{X} 8$ \\
\hline
\end{tabular}

Example Assignment to an expert: Evaluate on a scale from 0 to 100 the degree to which each of the criteria is met, where 0 is the lowest degree of conformity and 100 is the highest.

Table 6. Results of the audit of quality assurance and compliance of the innovative project with national regulations and standards

\begin{tabular}{|c|l|c|c|}
\hline No. & \multicolumn{1}{|c|}{ Criterion name } & $\begin{array}{c}\text { Weight } \\
\text { (significance) }\end{array}$ & $\begin{array}{c}\text { Points } \\
\text { (estimate) }\end{array}$ \\
\hline 1 & $\begin{array}{l}\text { Availability of a certificate of conformity, according to } \\
\text { the state standard }\end{array}$ & 0.30 & $\mathrm{X} 1$ \\
\hline 2 & Availability of a fire safety certificate & 0.30 & $\mathrm{X} 2$ \\
\hline 3 & $\begin{array}{l}\text { Availability of a sanitary and epidemiological } \\
\text { certificate }\end{array}$ & 0.30 & $\mathrm{X} 3$ \\
\hline 4 & Availability of other certificates & 0.10 & $\mathrm{X} 4$ \\
\hline & Total & $\mathbf{1 . 0 0}$ & $\mathbf{X}_{\mathbf{N}}$ \\
\hline
\end{tabular}

Assignment to an expert: evaluate, using a scale from 0 to 100, the presence of documents that ensure quality and compliance with the standards of the Russian Federation, where 0 is the absence of a document declared in the criterion, and 100 is its 
availability (a point of 100 is assigned if a document is available, in case of absence, a point of 0 is assigned)

\section{Substantiation of technological calculations}

Here: Substantiation of the composition and quantity of the main equipment. Calculation of the need for labor resources. Calculation of time norms. Substantiation of the need for material and energy resources. Assessment of labor productivity. Development of estimated standards for innovation.

\section{Assessment of the innovative competence of the project participants (Tab. 7).}

Table 7. Results of the quality audit of the organization of management of an innovative project

\begin{tabular}{|c|l|c|c|}
\hline No. & \multicolumn{1}{|c|}{ Criterion name } & $\begin{array}{c}\text { Weight } \\
\text { (significance) }\end{array}$ & $\begin{array}{c}\text { Points } \\
\text { (estimate) }\end{array}$ \\
\hline 1 & $\begin{array}{l}\text { Experience in introducing new products to the market / } \\
\text { implementing similar projects }\end{array}$ & 0.50 & $\mathrm{X} 1$ \\
\hline 2 & $\begin{array}{l}\text { Availability of human resources for project } \\
\text { implementation }\end{array}$ & 0.20 & $\mathrm{X} 2$ \\
\hline 3 & $\begin{array}{l}\text { Availability of certified specialists in the field of } \\
\text { project management }\end{array}$ & 0.15 & $\mathrm{X} 3$ \\
\hline 4 & $\begin{array}{l}\text { Availability of a project management information } \\
\text { system in the organization }\end{array}$ & 0.10 & $\mathrm{X} 5$ \\
\hline 5 & $\begin{array}{l}\text { Availability of the Quality Management System in the } \\
\text { organization }\end{array}$ & $\mathbf{1 . 0 0}$ & $\mathbf{X}_{\mathbf{N}}$ \\
\hline & Total & & \\
\hline
\end{tabular}

\section{Economic assessment of constructive innovative solutions for a construction} object (constructive, technological solutions, space-planning, architectural solutions)

Here: Study and selection of methods for the economic assessment of design solutions. Comparison of the basic and proposed options in terms of production cost, price, cost of materials and components used, advantages and disadvantages of production technology, equipment. Development and analysis of the price-quality criterion (Tab. 8).

Table 8. Economic assessment of adopted innovative solutions

\begin{tabular}{|c|l|c|c|}
\hline No. & \multicolumn{1}{|c|}{ Criterion name } & $\begin{array}{c}\text { Weight } \\
\text { (significance) }\end{array}$ & $\begin{array}{c}\text { Points } \\
\text { (estimate) }\end{array}$ \\
\hline 1 & $\begin{array}{l}\text { Reducing the resource intensity of construction production } \\
\text { (capital intensity; material consumption; energy intensity) }\end{array}$ & 0.1 & $\mathrm{X} 1$ \\
\hline 2 & Improving working conditions and increasing productivity & 0.05 & $\mathrm{X} 2$ \\
\hline 3 & Reducing the duration of technological operations & 0.05 & $\mathrm{X} 3$ \\
\hline 4 & $\begin{array}{l}\text { Improving the quality of completed construction and } \\
\text { installation work }\end{array}$ & 0.05 & $\mathrm{X} 4$ \\
\hline 5 & Acceleration of object commissioning & 0.05 & $\mathrm{X} 5$ \\
\hline 6 & $\begin{array}{l}\text { Acquisition of innovative aesthetic, technical and } \\
\text { technological characteristics by the object put into } \\
\text { operation }\end{array}$ & 0.05 & $\mathrm{X} 6$ \\
\hline 7 & Significant reduction in facility operating costs & 0.2 & $\mathrm{X} 7$ \\
\hline 8 & Extension of the period between repairs & 0.2 & $\mathrm{X} 8$ \\
\hline 9 & $\begin{array}{l}\text { Minimizing the payback period for additional capital } \\
\text { investments by reducing operating costs }\end{array}$ & 0.05 & $\mathrm{X} 9$ \\
\hline 10 & $\begin{array}{l}\text { Price-quality ratio: } \\
\text { specific capital investments; unit operating costs; } \\
\text { additional commercial indicators (net present value; }\end{array}$ & 0.2 & $\mathrm{X} 10$ \\
\hline
\end{tabular}




\begin{tabular}{|l|l|c|c|}
\hline & $\begin{array}{l}\text { profitability; payback period); } \\
\text { unique quality characteristics of the object }\end{array}$ & & \\
\hline & Total & $\mathbf{1 . 0 0}$ & $\mathbf{X}_{\mathbf{N}}$ \\
\hline
\end{tabular}

\section{Environmental expertise and general assessment of the project}

Here: assessment of the level of negative impact on the environment (Tab.9).

Table 9. General assessment of the level of innovativeness of the project

\begin{tabular}{|c|l|c|c|}
\hline No. & \multicolumn{1}{|c|}{ Criterion name } & $\begin{array}{c}\text { Weight } \\
\text { (significance) }\end{array}$ & $\begin{array}{c}\text { Points } \\
\text { (estimate) }\end{array}$ \\
\hline 1 & $\begin{array}{l}\text { Scientific and technical novelty of the evaluated } \\
\text { product }\end{array}$ & 0.25 & $\mathrm{X} 1$ \\
\hline 2 & Assessment of the project management organization & 0.25 & $\mathrm{X} 2$ \\
\hline 3 & $\begin{array}{l}\text { Quality assurance and compliance with RF } \\
\text { regulations }\end{array}$ & 0.25 & $\mathrm{X} 3$ \\
\hline 4 & Environmental safety & 0.25 & $\mathrm{X}$ \\
\hline & Total & $\mathbf{1 . 0 0}$ & $\mathbf{X}_{\mathbf{N}}$ \\
\hline
\end{tabular}

\section{Final assessment of the level of innovation of the selected technological solutions}

$$
L_{X}=\sum_{i=1}^{N} X_{i}
$$

$L_{X}$-general technical and economic assessment of design solutions; $X_{i}-$ value of points according to target criteria; $N$ - is the number of criteria.

The calculated value obtained should be evaluated according to the proposed scale (Tab.10).

Table 10. Point scale of assessment

\begin{tabular}{|c|c|c|}
\hline Low level & Middle level & High level \\
\hline$L_{X}=200-349$ & $L_{X}=350-449$ & $L_{X}=450-600$ \\
\hline
\end{tabular}

\section{Results}

The proposed instruments for activating innovative processes in major construction are part of the organizational and economic mechanism for managing investment and innovation activities in major construction.

The author holds the view that construction activities are regional in nature. Therefore, the area of performance study should be limited to territorial and administrative boundaries. Based on the foregoing, investment in innovation has a significant impact on the value of the gross regional product due to the emergence of a regional multiplicative effect (or cross-effect).

The multiplicative effect is the effect that occurs when the dependent variable rises in excess of the initial impulse. Therefore, it is important that the effect of the introduction of innovations manifests itself not as a local effect of the implementing company, but as a cross-effect isolated and determined at each stage of the construction project and for all participants (Fig. 1). 


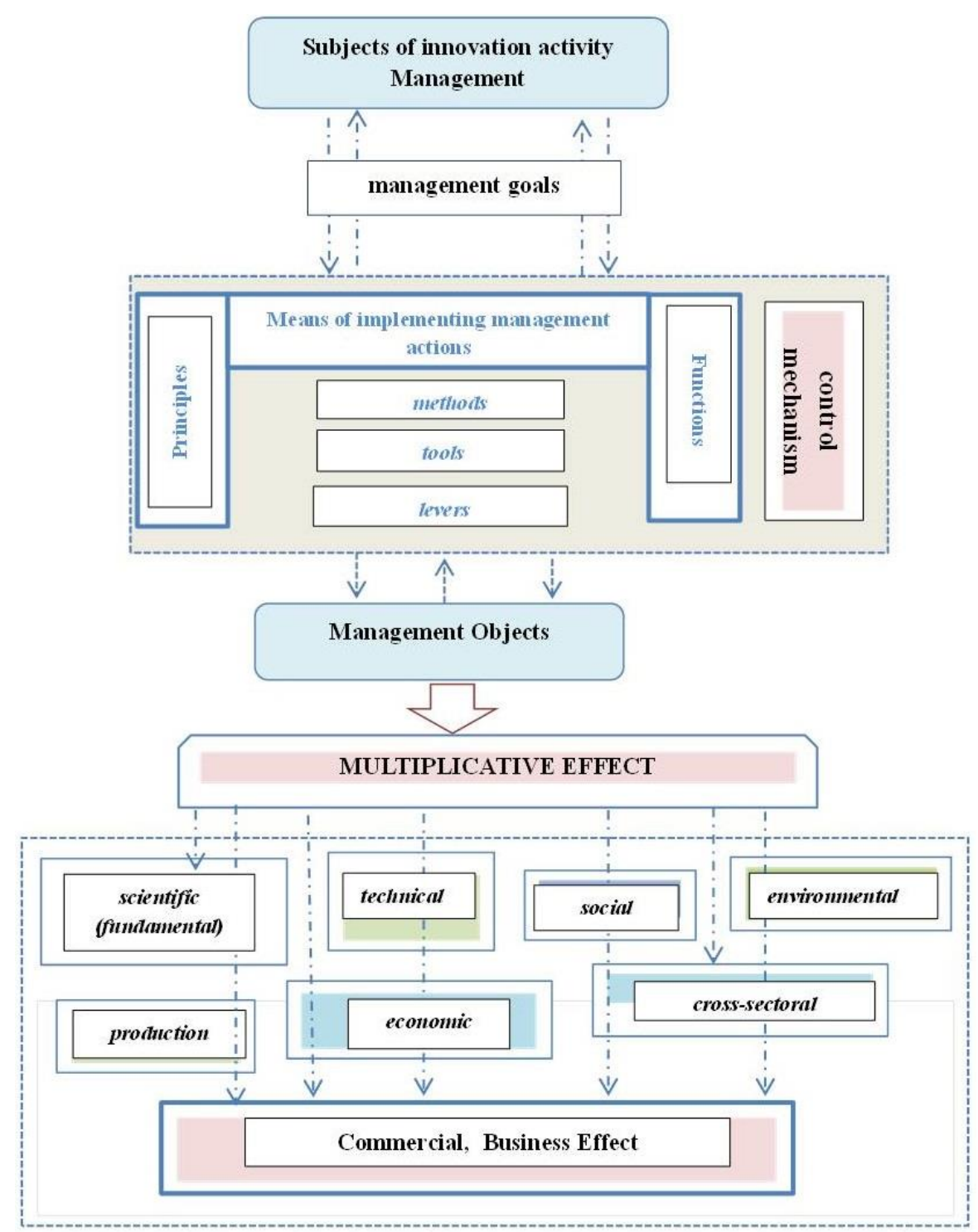

Fig. 1. Model of the organizational and economic mechanism of innovation management

\section{Discussions}

The dual nature of the multiplicative effects generated by investment and innovation activities in any sector of the economy should be noted. Not all innovative solutions have innovative potential manifested during the period of interaction of all participants in investment and construction activities.

Therefore, in the study of the effectiveness of innovative activities in major construction, the final result obtained after the implementation of the project should be divided into design stages, and the cross-effects that arise at each stage should be studied. Moreover, if the effect of the introduction of innovation has a positive value on each participant in investment and construction activities, then we should talk about the 
manifestation of a cross-effect. Otherwise, when the introduced innovation affects the economic result of only one subject, then we should talk about a local manifestation.

It should be noted that the effect can be both positive and negative. It is known that the influence of the multiplicative effects formed by investments complicates the development of the innovation system. For example, their action can cause a lack of resources in the region.

\section{Conclusion}

Therefore, multiplicative effects contribute to the formation of instability of the analyzed processes, changing the trajectory of their development, lead to the emergence of additional demand, provoking inflation. As a result of these effects, the purposeful development of the innovation sector of the economy can lead to unplanned results. Even if they are positive, it will complicate the planning and control processes.

Consequently, the action of the multiplicative effects arising as a result of innovative activities is subject to separate scientific and practical study.

\section{References}

1. L. Gokhberg, K. Ditkovsky, E. Evnevich and others. Indicators of innovative activity: 2020: statistical collection . NRU HSE. 336 p. (2020)

2. Science. Technologies. Innovation: 2021: A Brief Statistical Compendium. NRU HSE (2021).

3. V. Politi . AISC (Adv. in Intell. Syst. and Comput.). 983, 116-126. (2019),

4. E. Kuicheva, A. Popov. Regional Research of Russia (Road Town, United Kingdom), 6, no.1, pp. 9-20 (2017)

5. E.M. Rogers. Diffusion of Innovations, New York: Simon and Schuster, 2010, 4th ed.

6. E. Nezhnikova. Proc. Eng. 165, 1300-130. (2016).

7. F. Sleznov, Regional Research of Russia, 10, no.1, 97-106 (2020)

8. B. Zhikharevich., O. Rusetskaya, Regional Research of Russia (Road Town, United Kingdom), 8, no. 1, pp. 31-42 (2018).

9. V. Kosarev, P. Pavlov, and A. Kaukin, Ekon. Polit., 14, no. 5, pp. 144-149 (2019).

10. D. Morkovkin, D. Lopatkin, T. Shushunova.N., B. Sharipov, A. Gibadullin. Formation of the conditions for the development of innovation in Journal of Physics: Conference Series, IOP Publishing ([Bristol, UK], England), 1515, no. 3, p. 032002 (1-6) (2020).

11. A. Lapidus. Applied Mechanics and Materials. Trans Tech Publications. Switzerland. Vol. 584-586. Pp. 2230-2232 (2014). 